\title{
DISCOVERY OF YELLOW-BELLIED MARMOTS IN THE PILOT RANGE: IMPLICATIONS FOR SPECIES DISTRIBUTION MODELS IN THE GREAT BASIN
}

\author{
Chris H. Floyd ${ }^{1}$
}

\begin{abstract}
The array of island-like mountains that characterizes the Great Basin has long been a model system for studying the effects of past and present climate change on distributions of montane mammals. One of the smallest of these mountains is the Pilot Range (Nevada/Utah). This range has relatively few species of montane mammals, presumably because of its small size and the fact that it was isolated by the waters of Lake Bonneville during much of Pleistocene. One of the species previously assumed to be absent in the Pilot Range is the yellow-bellied marmot (Marmota flaviventris). On 23 May 2016, I documented marmots living in the Patterson Pass area of the Pilot Range. This discovery shows how the use of high-resolution satellite images and geological maps combined with a good understanding of the species' habitat provides an excellent opportunity to confirm the presence or accurately infer the absence of a species in a remote, rugged location.
\end{abstract}

Resumen.-El conjunto de montañas, similares a islas, que caracterizan la Gran Cuenca es, desde hace un largo tiempo, un sistema modelo para estudiar los efectos del cambio climático del presente y el pasado, y su efecto en la distribución de los mamíferos de la zona. Una de las montañas más pequeñas es la Cordillera Pilot (Nevada/Utah). Esta cordillera presenta, relativamente pocas especies de mamíferos montañosos, presumiblemente por su tamaño pequeño y al hecho de que estuvo aislada por las aguas del Lago Bonneville durante gran parte del Pleistoceno. Una de las especies supuestamente ausentes en la Cordillera Pilot es la marmota de vientre amarillo (Marmota flaviventris). El 23 de mayo de 2016, documenté marmotas viviendo en el área de Patterson Pass, en la Cordillera Pilot. Este descubrimiento demuestra cómo el uso de imágenes satelitales de alta resolución y de mapas geológicos, combinados con una buena comprensión del hábitat de las especies ofrecen una excelente oportunidad para confirmar la presencia o inferir, con precisión, la ausencia de una especie en un lugar remoto y agreste.

To model the effects of climate change on a species' distribution, it is essential to have a list of locations where the presence of the species has been confirmed. In some cases, this information is available from archived or published records, but oftentimes new field surveys must be conducted. The accuracy of species distribution modeling would be further improved if the investigator had a list of locations where absence has been documented, but this information is rarely available (Boakes et al. 2016). For logistical reasons, it is commonly the case that the areas where a species is presumed to be absent were searched less thoroughly than areas where the species was found (Phillips et al. 2009). Consequently, species distribution modelers are often forced to use randomly drawn points representing "pseudo-absence" in lieu of field-based absence data (Phillips et al. 2009).

The more difficult an area is to reach and survey, the more challenging it is to confirm species presence/absence. Such logistical constraints are common in the Great Basin, a vast region of western North America characterized by long, narrow mountain ranges separated by arid valleys. Much of the area above $2000 \mathrm{~m}$ elevation is complex terrain composed of thousands of ridges, peaks, and canyons that are inaccessible by vehicle. Therefore, even a well-funded biogeographical survey would likely miss substantial portions of a mountain range in the Great Basin.

The Great Basin has long attracted researchers interested in the effects of past and present climate change on the distributions of montane (i.e., mountain-dwelling, coldadapted) mammals (Riddle et al. 2014). The reasons for this attraction include the islandlike nature of many Great Basin ranges and the fact that most of the ranges contain only a subset of the region's total species richness (thus implying selective extinction or colonization;

1Department of Natural Resources Science, 102 Coastal Institute, University of Rhode Island, Kingston, RI 02881. E-mail: floydch@uri.edu 
Lawlor 1998). During the Late Glacial Maximum (LGM) montane mammals in the Great Basin lived at lower latitudes and lower elevations than they do today (Grayson 2011). As a result of Holocene warming and the associated desertification of the intervening valleys, the southern/lower-elevation limits of montane mammals shifted north/upslope; and, consequently, some species disappeared from some ranges (Grayson 2011). In his seminal study, Brown (1971) proposed that the modern distribution of montane mammals in the Great Basin was a product of colonization during the Pleistocene followed by isolation and extinction during the Holocene. A key piece of evidence for this nonequilibrium model was the nested distribution of montane mammals on insular Great Basin ranges; namely, the lists of species on mountain ranges with lower species richness were subsets of those on ranges with the full complement of species. For example, species richness of montane mammals on the White Mountains (California) and Grant-Quinn Canyon Range (Nevada) is 13 and 6, respectively, the latter 6 being included among the former 13 (Lawlor 1998).

Surveys conducted since Brown's (1971) study revealed the presence of some montane species on ranges where the species was presumably absent. For example, Grayson and Livingston (1993) conducted surveys in the Diamond and Roberts ranges (Nevada) and documented the presence of yellow-bellied marmots (Marmota flaviventris) and Nuttall's cottontails (Sylvilagus nuttallii), which had not been previously recorded in those ranges. Indeed, Brown (1971) predicted that some of the absences in his study were omissions that would be corrected with "more intensive collecting." The results of analyses using updated species lists indicated that the extent of isolation or extinction in the Great Basin was not as high as that predicted by the nonequilibrium model (Lawlor 1998). Below I describe my recent discovery of yellow-bellied marmots living in the Pilot Range, where Brown and other investigators had assumed the species to be absent.

\section{Methods}

The Pilot Range is the smallest of the 19 island-like ranges considered by Brown (1971, 1978). Approximately $37 \mathrm{~km}$ long and $2-5 \mathrm{~km}$ wide (the spans between $2000 \mathrm{~m}$ contour intervals), the Pilot Range straddles the border of Nevada (Elko County) and Utah (Box Elder County) (Fig. 1A and 1B). My searches of the literature (e.g., Shippee and Egoscue 1958), museum collection databases (e.g., VertNet 2016, ARCTOS 2016), and E.R. Hall's archived field notes (MVZ 2015) revealed no evidence that yellow-bellied marmots resided in the Pilot Range. The species occupies at least 28 named mountain ranges in the Great Basin (Floyd 2004; C. Floyd unpublished data), but they were not among the species listed as occurring in the Pilot Range by Brown (1971, 1978) or in the papers that followed up on his work (Grayson and Livingston 1993, KodricBrown and Brown 1993). In all those studies, the investigators conducted surveys of their own, but they also relied on published compendiums of mammal distributions in Nevada (Hall 1946) and Utah (Durrant 1952, Durrant et al. 1955). Brown (1971) noted that his field surveys "concentrated on the small mountain ranges," which presumably included the Pilot Range. Modern-day presence of marmots has been noted in the Goose Creek and the Spruce Mountain ranges (Fig. 1A), which are located approximately $50 \mathrm{~km}$ from the Pilot Range and were the spatially closest observations that I could find (Floyd 2004, Swanson 2011; Fig. 1A). The closest observations from the paleontological record came from excavations at Danger Cave in the Silver Island Mountains - a relatively low, arid range located approximately $20 \mathrm{~km} \mathrm{SE}$ of the Pilot Range (Fig. 1A) —where the marmot record ends at ca. 10,500 BP (Grayson et al. 1988).

The lack of information on marmots on the Pilot Range reflects what appears to be a general dearth of published literature on any ecological aspect of the range. This observation led me to suspect that much of the Pilot Range had been overlooked in previous surveys. In particular, I wondered if previous surveys had focused mostly on the southern part of the range, especially in the vicinity of its tallest summit, Pilot Peak (3270 m elevation above sea level; Fig. 1B). This is arguably the best area in which to survey mammalian diversity because that is where the range's greatest elevation gradient exists-namely, the almost 2000-m elevation change from the valley bottom to the top of Pilot Peak. However, there is considerable variation in bedrock type and associated 

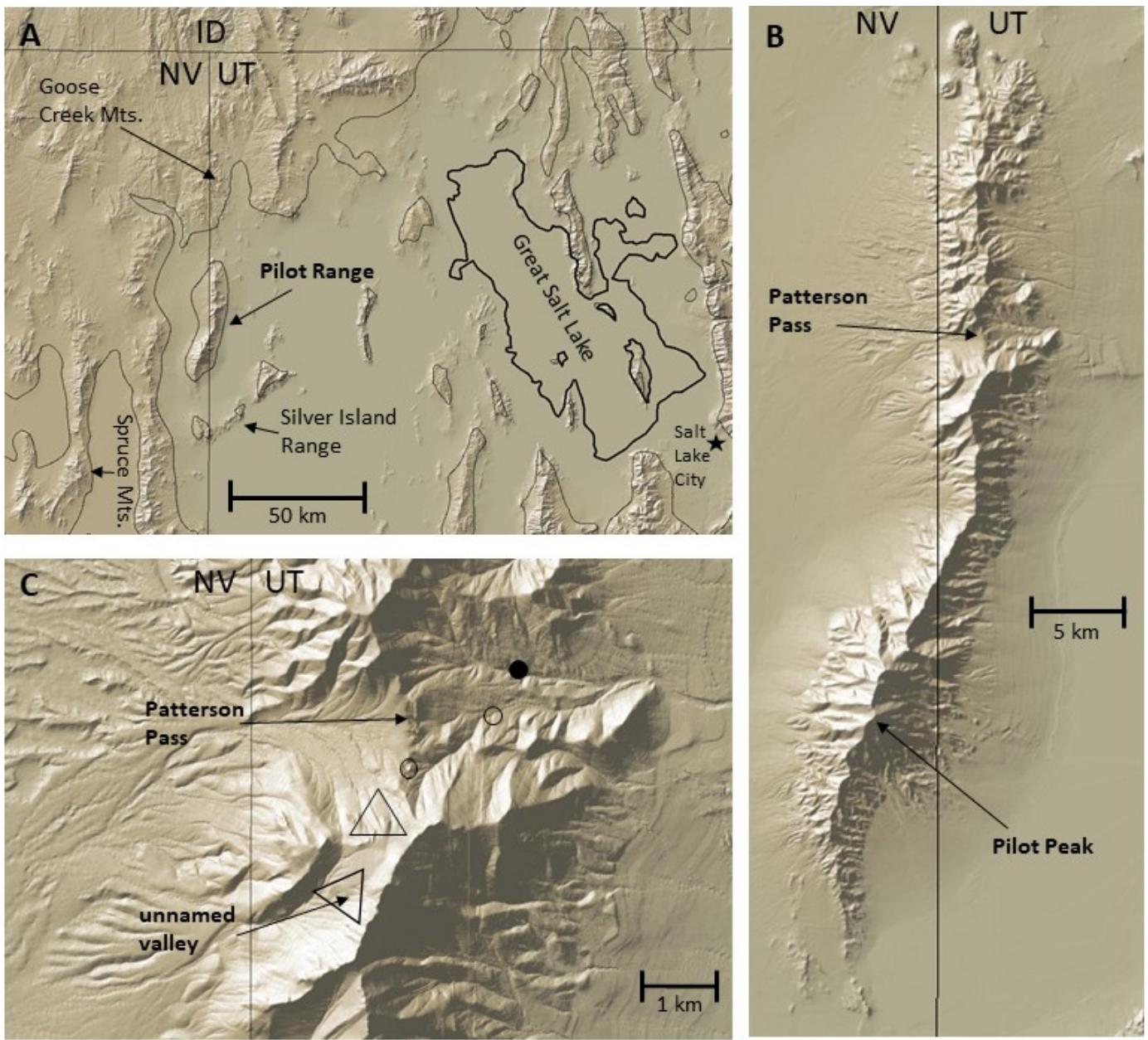

Fig. 1. (A) Location of the Pilot Range in context of surrounding mountains in the Great Basin of western North America, USA. Light lines show shorelines of pluvial lakes, the largest of which (Lake Bonneville) isolated the Pilot Range during the Last Glacial Maximum (Grayson 2011). (B) North-to-south extent of the Pilot Range. (C) Area where C.H. Floyd searched for yellow-bellied marmots (Marmota flaviventris) on 23 May 2016. The filled circle shows the site of the only marmot directly observed that day; fresh scats of marmots were found at that site and 2 others (open circles). No evidence of marmots was found within the areas indicated by triangles, despite extensive searching and an abundance of optimal-looking habitat. Map images were generated using the Global Multi-Resolution Topography Synthesis basemaps (Ryan et al. 2009) in GeoMapApp 3.6.4 (http://www.geomapapp.org).

vegetation across the long axis of the range, which could produce heterogeneity in faunal distributions. The bedrock in the southern part of the Pilot Range (including Pilot Peak) is primarily limestone/dolostone and quartzite/ siltstone (Hintze et al. 2000, Crafford 2010). Erosion of this rock has created vast fields of talus ringed by conifers. Satellite and groundlevel photos (Google Earth and associated user-uploaded photos) show that the Pilot Peak area lacks the shrubby montane meadows generally associated with marmots (Floyd 2004).
In contrast to the southern half of the Pilot Range, my satellite photo-based examinations of the northern half revealed at least 2 areas that seemed promising for marmot occupancy. My eye was particularly drawn to the open terrain surrounding Patterson Pass. That area has been the focus of efforts by federal and state wildlife managers (BLM 1979, UDWR no date) to maintain and enhance habitat for elk (Cervus elaphus), a species that (like marmots) prefers shrubby montane meadows for summer forage (Beck and Peek 2005). 

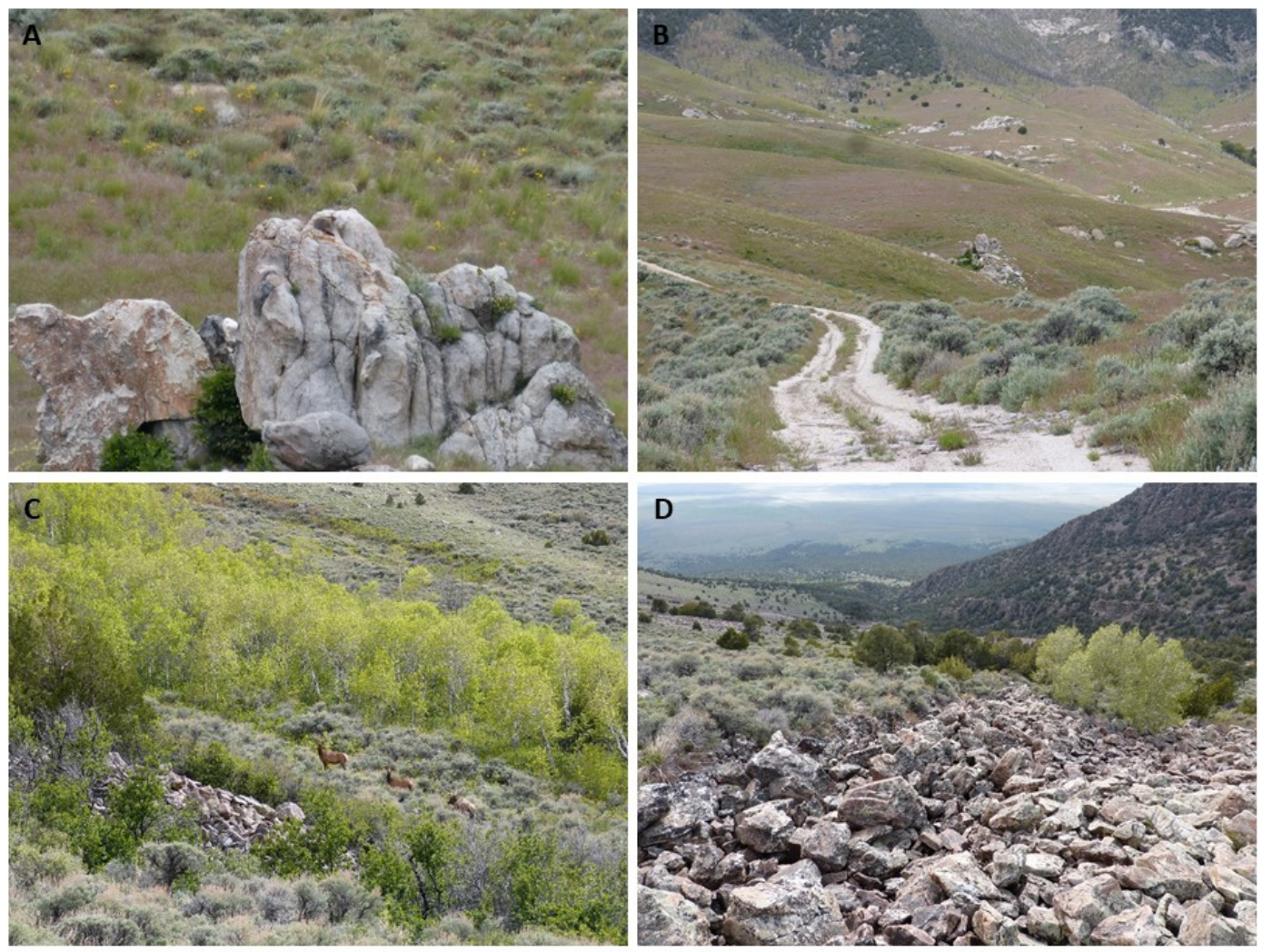

Fig. 2. Photographs of sites in the Patterson Pass area of the Pilot Range, Utah, taken on 23 May 2016, when C. Floyd searched the area for yellow-bellied marmots. (A) Rock prominence with adult marmot on top. (B) Granite outcrops and surrounding meadows on the east side of Patterson Pass. (C) One of several talus-like accumulations with surrounding aspens (Populus tremuloides) and shrubs on a slope approximately $1 \mathrm{~km} \mathrm{SW}$ of Patterson Pass. Three bull elk (Cervus elaphus) are visible in the center of the photo. (D) Unnamed valley approximately $2 \mathrm{~km} \mathrm{SW}$ of Patterson Pass. No sign of marmots was found in the areas represented by images C and D. Photos by C.H. Floyd.

North-northeast of the pass along the eastern slope of the Pilot Range is a large swath of bedrock composed of tertiary intrusive granodiorite (Hintze et al. 2000), which is exposed as numerous white granite outcrops (Fig. 2B). It struck me that this matrix of meadow and granite outcrops resembled that in Scott's Basin, a valley in the Deep Creek Range (Utah) where I had found marmots to be common (Floyd 2004). Other favorable-looking locations included the areas upslope of Patterson Pass (along the spine of the Pilot Range; Fig. 2C) and an unnamed valley approximately $3 \mathrm{~km}$ to the southwest of the pass (Fig. 2D). The unnamed valley, which drains into the western (Nevada) side of the Pilot Range, contains many talus-like accumulations embedded in shrubby meadows, some of which were ringed by clusters of small aspen trees (Populus tremuloides; Fig 2D).

\section{RESUlTs}

On the afternoon of 23 May 2016, I parked my vehicle at $1613 \mathrm{~m}$ elevation (where the road was washed out) and walked up the steep 4-wheel-drive road to Patterson Pass. At 21:14 UTC, I saw and photographed one adult marmot that was lying on top of a granite outcrop at approximately $1795 \mathrm{~m}$ elevation (Fig 2A; UTM coordinates: 12T, $249069.33 \mathrm{~m} \mathrm{E}$, $4564962.90 \mathrm{~m} \mathrm{~N}$ ). My ensuing examination of this outcrop and 2 others located upslope of the first sighting $(12 \mathrm{~T}, 248565.19 \mathrm{~m} \mathrm{E}$, $4564412.09 \mathrm{~m} \mathrm{~N}$ and 11T, $750668.03 \mathrm{~m} \mathrm{E}$, $4563647.67 \mathrm{~m} \mathrm{~N}$ ) revealed accumulations of fresh and desiccated marmot scats, which are commonly found on rock prominences used by marmots as lookout posts (Floyd 2004). My subsequent searches, which were carried out 
during the 4 hours before sunset that same day, focused on the southwest side of Patterson Pass (approximate center point: 11T, $750079.16 \mathrm{~m} \mathrm{E}$, $4562914.53 \mathrm{~m} \mathrm{~N}$; Figs. 1C, 2C) and upper portions of the unnamed valley (approximate center point: 11T, $749537.23 \mathrm{~m} \mathrm{E}, 4561470.96 \mathrm{~m} \mathrm{~N}$, Figs. 1C, 2D). Despite the abundance of what looked like optimal marmot habitat in those locations, I failed to find any sign of marmots. Weather conditions throughout the survey were not ideal for observing marmots (mostly cloudy, passing showers, and temperatures approximately $10{ }^{\circ} \mathrm{C}$ to $18{ }^{\circ} \mathrm{C}$ ). However, there were multiple bouts of sunshine that would likely have encouraged any local marmot to emerge from its burrow, during which time I expected I would have heard the loud alarm calls that marmots typically give when they spot a potential predator (Floyd 2004). The fact that I did not hear the calls or find the scats of marmots in the unnamed valley indicates that the species was not common in that area.

The addition of marmots to the list of mammals in the Pilot Range brings its known species richness of montane mammals up to 4 , which equals or exceeds the value on only 3 of the other 18 mountain ranges considered in Brown's studies (Brown 1971, 1978, Grayson and Livingston 1993). The low species richness is presumably due to the small size of the Pilot Range and the fact that, unlike the other ranges, it was surrounded by the waters of Lake Bonneville during the LGM (Fig. 1A, Grayson 2011). Indeed, the latter characteristic was the reason that Lawlor (1998) excluded the Pilot Range from his study as being too atypical; namely, the lake would have completely isolated the Pilot Range during a time when other Great Basin ranges were connected by habitats crossable by montane mammals (Grayson 2011). The discovery of marmots in the Pilot Range is to my knowledge the only example of marmots currently occupying a mountain range that was once completely surrounded by the waters of Lake Bonneville (Grayson et al. 1988, Grayson 2011).

\section{Discussion}

I argue that the topographical complexity and remoteness that typifies mountain ranges in the Great Basin makes it nearly impossible to confidently reject the hypothesis that a species marmot-sized or smaller is present on a particular range. Even the relatively tiny Pilot Range has at least 31 springs, 27 streams, and 14 named canyons (as indicated on USGS 7.5minute, 1:24,000-scale quadrangle maps), all of which would need to be explored if a thorough search of marmot habitat was conducted in the range. Another remote, island-like range in which marmots are presumably absent (Brown 1971, Lawlor 1998) is the Grant-Quinn Canyon Range (NV), which is over 10 times larger than the Pilot Range (Brown 1978) and contains hundreds of springs, streams, and canyons. It would surely take years for a survey team to cover the Grant-Quinn Canyon Range thoroughly enough to permit the investigator to feel confident that a survey's failure to find marmots reflected the true absence of that species in the range. Confirming absence would be even more problematic for relatively small, inconspicuous mammals such as the short-tailed weasel (Mustela erminea) and water shrew (Sorex palustris), both of which are presumed to be absent on the Pilot and Grant-Quinn Canyon ranges (Brown 1971, Grayson and Livingston 1993). Nonetheless, I propose that the growing availability of high-resolution satellite images (e.g., Google Earth) and GIS layers (e.g., Bradley and Mustard 2005), combined with the predictive power of species distribution models (SDMs) (e.g., Waltari and Guralnick 2009), provides modern surveyors with an excellent opportunity to focus their efforts on a few specific locations and document the presence of a species in an area, if in fact it occurs there (e.g., Malaney et al. 2016). Likewise, a failure to find the species in optimal/predicted habitat will result in a documented absence that is of much greater utility than the pseudo-absence data points used in SDMs lacking field-based information on absence (Phillips et al. 2009).

\section{ACKNOWLEDGMENTS}

I appreciate the occasional housing provided by R. Buiser, M.K. Buiser, L. Moyer-Horner, S. Yeo, and R. Miller during my 2016 fieldwork in the Great Basin. Also, 2 anonymous reviewers made helpful comments.

\section{Literature Cited}

ARCTOS. 2016. Arctos Collaborative Collection Management Solution. [Accessed 10 April 2016]. https:// arctosdb.org 
Beck, J.L., AND J.M. Peek. 2005. Diet composition, forage selection, and potential for forage competition among elk, deer, and livestock on aspen-sagebrush summer range. Rangeland Ecology and Management 58:135-147.

Boakes, E.H., R.A. Fuller, P.J.K. McGowan, and G.M. MACE. 2016. Uncertainty in identifying local extinctions: the distribution of missing data and its effects on biodiversity measures. Biology Letters 12: 20150824

Bradley, B.A., AND J.F. Mustard. 2005. Identifying land cover variability distinct from land cover change: cheatgrass in the Great Basin. Remote Sensing of Environment 94:204-213.

Brown, J.H. 1971. Mammals on mountaintops: nonequilibrium insular biogeography. American Naturalist 105:467-478.

Brown, J.H. 1978. The theory of insular biogeography and the distribution of boreal birds and mammals. Great Basin Naturalist Memoirs 1978:209-227.

[BLM] Bureau of Land Management. 1979. Pilot Mountain Habitat Management Plan (UT-02-WHA-T-11) and Environmental Assessment Record (UT-020-858). Prepared by E.R. Gomer and D. Duff. Bureau of Land Management, Salt Lake City, UT; [digital library accessed 25 May 2017]. http://cdm15879 .contentdm.oclc.org/cdm/compoundobject/collection/ p15879coll13/id/16878

CrafFord, A.E. 2010. Geological terrane map of Nevada. Nevada Bureau of Mines and Geology. [Accessed 15 May 2016]. http://data.nbmg.unr.edu/public/free downloads/of/of2010-04.zip

Durrant, S.D. 1952. Mammals of Utah: taxonomy and distribution. University of Kansas Publications of the Museum of Natural History 6:1-549.

Durrant, S.D., M.R. LeE, and R.M. Hansen. 1955. Additional records and extensions of known ranges of mammals from Utah. University of Kansas Publications of the Museum of Natural History 9:75-76.

FLOYD, C.H. 2004. Marmot distribution and habitat associations in the Great Basin. Western North American Naturalist 64:471-481.

Grayson, D.K, 2011. The Great Basin: a natural prehistory. University of California Press, Berkeley, CA.

GraYson, D.K., AND S.D. LivingSTON. 1993. Missing mammals on Great Basin mountains: Holocene extinctions and inadequate knowledge. Conservation Biology 7:527-532.

Grayson, D.K., P.W. Parmalee, R.L. Lyman, and J.I. MEAD. 1988. Danger Cave, Last Supper Cave, and Hanging Rock Shelter: the faunas. Anthropological Papers of the AMNH 66(1)

HaLL, E.R. 1946. Mammals of Nevada. University of California Press, Berkeley, CA. 432 pp.

Hintze, L.F., G.C. Willis, D.Y.M. Laes, D.A. SpRinkel, AND K.D. BRown. 2000. Digital geologic map of Utah [online]. Utah Geological Survey, Salt Lake City, UT. https://geology.utah.gov/apps/intgeomap/ index.html
Kodric-Brown, A., AND J.H. Brown. 1993. Incomplete data sets in community ecology and biogeography: a cautionary tale. Ecological Applications 3:736-742.

LAWLOR, T.E. 1998. Biogeography of Great Basin mammals: paradigm lost? Journal of Mammalogy 79: $1111-1130$

Malaney, J.L., B.A. Kohli, M.A. Hobbs, B.C. Rapier, L.P. SMITH, AND M.D. MatocQ. 2016. New records and two possible local extinctions from a sky island in the Great Basin. Poster \#155, 2016 Meeting of the American Society of Mammalogists, Minneapolis, MN; [accessed 1 June 2017]. http://www.mammal society.org/uploads/2016-ASM-abstracts-2016 .05.18.pdf

[MVZ] Museum of Vertebrate Zoology. 2015. EcoReader. University of California, Berkeley, CA; [accessed 10 May 2015]. http://ecoreader.berkeley.edu

Phillips, S.J., M. Dudík, J. Elith, C.H. Graham, A. Lehmann, J. Leathwick, and S. Ferrier. 2009. Sample selection bias and presence-only distribution models: implications for background and pseudo-absence data. Ecological Applications 19:181-197.

Riddle, B.R., T. Jezkova, A.D. Hornsby, and M.D. MatocQ. 2014. Assembling the modern Great Basin mammal biota: insights from molecular biogeography and the fossil record. Journal of Mammalogy 95:1107-1127.

Ryan, W.B., S.M. Carbotte, J.O. Coplan, S. O'Hara, A. Melkonian, R. Arko, R.A. Weissel, V. Ferrini, A. Goodwillie, F. Nitsche, and J. Bonczkowski. 2009. Global Multi-Resolution Topography synthesis. Geochemistry, Geophysics, Geosystems 10(3). https://doi.org/10.1029/2008GC002332

ShippeE, E.A., AND H.J. Egoscue. 1958. Additional mammal records from the Bonneville Basin, Utah. Journal of Mammalogy 39:275-277.

SWAnson, R.W. 2011. A comprehensive analysis of the Swallow Shelter (42BO268) faunal assemblage. Doctoral dissertation, Washington State University, Pullman, WA; [accessed 15 May 2016]. http://www .dissertations.wsu.edu/thesis/spring2011/r_swanson 041911.pdf

[UDW̄R] Utah Division of Wildlife. No date. Patterson Pass - trend study no. 1-23-11. Utah Division of Wildlife Resources, Salt Lake City, UT; [accessed 15 May 2016]. https://wildlife.utah.gov/range/pdf/ wmu01/01-23.pdf

VertNet. 2016. VertNet home page [online]. [Accessed 10 April 2016]. http://www.vertnet.org

Waltari, E., and R.P. GURALnick. 2009. Ecological niche modelling of montane mammals in the Great Basin, North America: examining past and present connectivity of species across basins and ranges. Journal of Biogeography 36:148-161.

Received 15 June 2017

Accepted 11 September 2017 Published online 24 October 2017 